\title{
Seasonal variations \\ in hematological values and heart weight in two small mammals, a mouse: Apodemus sylvaticus, and a vole: Pitymys duodecimcostatus
}

\author{
G. PÉREZ-SUÁREZ, F. ARÉVALO, E. LÓPEZ-CABALLERO \\ and P. LÓPEZ-LUNA
}

\begin{abstract}
Pérez-Suárez G., Arévalo F., López-Caballero E. and López-Luna P. 1990. Seasonal variations in hematological values and heart weight in two small mammals, a mouse Apodemus sylvaticus, and a vole: Pitymys duodecimcostatus. Acta theriol. 35: 201-208.

Hematological values and relative heart weight were analyzed in two rodents: the mouse, Apodemus sylvaticus (Linnaeus, 1758), and the vole, Pitymys duodecimcostatus (de Selys-Longchamps, 1839). The body weight of the two species was similar, $18.60 \pm 0.61 \mathrm{~g}$ for the mouse, versus $20.14 \pm 0.42 \mathrm{~g}$ for the vole. The specimens were captured in the same geographic area but in different ecological niches, since the vole is a burrowing animal, and the mouse is not. Hematological variations in both species were not related to age, sex, or gestation. $P$. duodecimcostatus had higher $\mathrm{RBC}$ count and $\mathrm{Hb}$ and $\mathrm{Hc}$ concentrations and lower MCV and MCH values than A. sylvaticus. However, MCHC values were almost the same in both species. The seasonal hematological variations observed in $P$. duodecimcostatus are like those found in most small mammals, while the hematological values found in $A$. sylvaticus barely changed throughout the year. The relative heart weight increased significantly in the two species during winter.
\end{abstract}

Departamento de Biología Animal, Universidad de Alcalá de Henares, 28871 Alcalá de Henares, Madrid, Spain

Key words: hematological values, heart weight, Apodemus sylvaticus, Pitymus duodecimcostatus

\section{Introduction}

The metabolic needs of animal tissues are met by hemoglobin based oxygen transport. For this reason the hematological parameters closely reflect $\mathrm{O}_{2}$ transport and partly explain organism adaptation for this vital requirement. Although the hemoglobin content of the blood and hematocrit in mammals are relatively constant, the total number of red blood cells and mean cell size varies considerably. An inverse relationship between cell size and number was pointed out by Hawkey (1975). Numerous small red blood cells are often found in those species which inhabit high altitudes or live underground, where the modification is thought to be an adaptation to low oxygen availability by providing increased surface area for gas exchange (Hawkey 1975).

The hematological variations found in different mammalian species have been studied with respect to possible influential factors such as acclimatization to different 
temperatures (Sealander 1960, 1962, Lee and Brown 1970), postnatal development (Kostelecka-Myrcha 1966a), altitude (Kalabukhov 1953, Sealander 1964), diet (Kunicki-Goldfinger and Kunicka-Goldfinger 1964), age (Sealander 1964, Wołk 1974, Barnett et al. 1979) or stress (Kunicki-Goldfinger and Kunicka-Goldfinger 1964). All these studies refer to the $\mathrm{O}_{2}$ transportation capacity of the blood as regulated by different external pressures to which the animals are subjected.

The blood parameter variation in relation to seasonal changes has been studied in different species od small mammals such as rats (Sealander 1962,1964), kangaroo rats (Scelza and Knoll 1982), rabbits (Dudziński et al. 1962), shrews (Kunicki and Kunicka 1964, Wołk 1974), and voles (Rewkiewicz-Dziarska 1975). These studies generally found that the hemoglobin and hematocrit values and the number of red blood cells tended to increase in winter and then decrease during summer. This is partly explained by the higher metabolic rates found in these animals in response to their acclimatization to lower winter temperatures.

Another factor contributing to improved circulatory efficiency, and therefore increased tissue oxygenation, is the increase in relative heart weight since this supposes an increased cardiac output per unit of weight. Other factors, such as photoperiod (Puchalski and Heldmaier 1986), acclimatization to cold (Heroux 1961, Malzahn 1974, Sealander 1966), or altitude (Kostelecka-Myrcha 1967) have also been described as influencing relative heart weight.

This study researched seasonal changes in certain physiological parameters related to the transport and delivery of oxygen to the tissues of two small mammals, Apodemus sylvaticus (Linnaeus, 1758), a mouse that lives above-ground, and Pitymys duodecimcostatus (de Sélys-Longchamps, 1839), a burrow-dwelling vole which lives underground.

\section{Materials and methods}

A total of 95 Apodemus sylvaticus and 90 Pitymys duodecimcostatus were caught in live traps near Alcalá de Henares (Madrid, Spain) between September, 1984 and September, 1985. The animals were anesthetized by ether inhalation and blood was obtained by heart puncture with sterile heparin-rinsed syringes. Red blood cells (RBC) were counted in a Thoma chamber and the hemoglobin concentration ( $\mathrm{Hb})$ was determined with the cyanomethemoglobin technique. The hematocrit (Hc) was determined by blood centrifugation in microhematocrit capillaries at $11,000 \mathrm{rpm}$ for 10 minutes. Mean corpuscular volume (MCV) was calculated from $\mathrm{RBC}$ count and $\mathrm{Hc}$; mean corpuscular hemoglobin $(\mathrm{MCH})$ was obtained from the $\mathrm{RBC}$ count and $\mathrm{Hb}$ concentration, and mean corpuscular hemoglobin concentration (MCHC) was calculated with the $\mathrm{Hc}$ and $\mathrm{Hb}$ concentrations. Once the animal was dead, the heart was extracted, cleaned of adherences and blood, and weighed on a Mettler scale to $\pm 0.1 \mathrm{mg}$. The values are expressed as relative weight in $\mathrm{mg}$ of organ weight per gram of body weight $(\mathrm{mg} / \mathrm{g})$. The age of each animal was estimated by weighing the crystalline lens of the eye fixed in $40 \%$ formol for 15 days and then drying it at $70^{\circ} \mathrm{C}$. Condylobasal length (CBL) was measured to within $\pm 0.1 \mathrm{~mm}$.

Data are expressed as means $\pm \mathrm{SE}$ and statistical significance was tested by analysis of variance (ANOVA), or by correlation coefficients $(r)$, where appropriate. The significance level was set at $0.05 \%$ 
unless otherwise stated. The calculations were made with a BMDP programme on an "Eclipse" MV4000 computer (Data General).

\section{Results}

The hematological values of both rodent species are shown in Table 1. The total results obtained indicate that hematological values for $\mathrm{RBC}, \mathrm{Hb}$ and $\mathrm{Hc}$ in $P$. duodecimcostatus were higher than in A. sylvaticus, while the MCV and MCH values were higher in the mouse than in the vole. The MCHC values were similar in both species.

Table 1. Hematological values (mean $\pm \mathrm{SE}$ ) of Apodemus sylvaticus, Pitymys duodecimcostatus and statistical significance ANOVA ( $\mathrm{ns}=$ not significant).

\begin{tabular}{|c|c|c|c|c|c|}
\hline Variable & Sign. & Males & Females & $\begin{array}{r}\text { Pregnant } \\
\text { females }\end{array}$ & Total \\
\hline \multicolumn{6}{|l|}{ A. sylvaticus } \\
\hline RBC $\quad\left(10^{6} / \mathrm{mm}^{3}\right)$ & ns & $9.52 \pm 0.21$ & $9.55 \pm 0.21$ & $8.96 \pm 0.30$ & $9.46 \pm 0.14$ \\
\hline$(\mathrm{g} / \mathrm{dl})$ & ns & $14.68 \pm 0.25$ & $14.96 \pm 0.36$ & $13.88 \pm 0.36$ & $14.59 \pm 0.18$ \\
\hline$(\%)$ & ns & $47.19 \pm 0.71$ & $47.09 \pm 1.18$ & $43.38 \pm 1.33$ & $46.59 \pm 0.57$ \\
\hline $\operatorname{MCV}\left(\mu^{3}\right)$ & ns & $48.91 \pm 0.64$ & $49.23 \pm 1.14$ & $48.75 \pm 1.74$ & $48.96 \pm 0.56$ \\
\hline $\mathrm{MCH} \quad$ (pg) & ns & $15.32 \pm 0.24$ & $15.39 \pm 0.39$ & $15.56 \pm 0.49$ & $15.39 \pm 0.19$ \\
\hline $\mathrm{MCHC}(\mathrm{g} \%)$ & ns & $31.34 \pm 0.39$ & $32.40 \pm 0.47$ & $32.53 \pm 0.59$ & $31.88 \pm 0.26$ \\
\hline $\mathrm{n}$ & & 52 & 25 & 18 & 95 \\
\hline \multicolumn{6}{|l|}{ P. duodecimcostatus } \\
\hline RBC $\quad\left(10^{6} / \mathrm{mm}^{3}\right)$ & ns & $12.13 \pm 0.24$ & $11.40 \pm 0.34$ & $11.21 \pm 0.49$ & $11.72 \pm 0.18$ \\
\hline$(\mathrm{g} / \mathrm{dl})$ & ns & $15.41 \pm 0.33$ & $14.84 \pm 0.33$ & $14.88 \pm 0.51$ & $15.08 \pm 0.23$ \\
\hline$(\%)$ & ns & $48.84 \pm 0.73$ & $47.22 \pm 1.08$ & $46.18 \pm 1.28$ & $47.86 \pm 0.56$ \\
\hline $\operatorname{MCV}\left(\mu^{3}\right)$ & ns & $42.14 \pm 0.72$ & $42.70 \pm 1.08$ & $42.62 \pm 1.25$ & $42.41 \pm 0.53$ \\
\hline $\mathrm{MCH} \quad$ (pg) & ns & $13.29 \pm 0.28$ & $13.20 \pm 0.30$ & $13.72 \pm 0.57$ & $13.82 \pm 0.20$ \\
\hline $\mathrm{MCHC}(\mathrm{g} \%)$ & ns & $31.51 \pm 0.46$ & $30.80 \pm 0.87$ & $32.21 \pm 0.80$ & $31.48 \pm 0.37$ \\
\hline $\mathrm{n}$ & & 46 & 25 & 19 & 90 \\
\hline
\end{tabular}

Effects of sex and gestation

No significant differences were observed in the variables analyzed in either sex of these species, although pregnant $A$. sylvaticus did show some decrease in RBC and the $\mathrm{Hc}$ and $\mathrm{Hb}$ concentrations.

\section{Effect of age}

Table 2 shows the correlation coefficient $(r)$ matrix for the different variables in relation to age: condylobasal length $(\mathrm{CBL})$, crystalline lens weight, animal weight and the hematological parameters for each species. Correlations between the hematological variables and the age-related variables were not significant. 
Table 2. Correlation coefficient $(r)$ matrix of hematological parameters and variables in relation to age (body weight, CBL, cristalline weight) for Apodemus sylvaticus and Pitymys doudecimcostatus $\left({ }^{*} p<0.05,{ }^{* * *} p<0.001\right)$.

\begin{tabular}{llllllll}
\hline \multirow{2}{*}{ Variable } & \multicolumn{3}{c}{ Apodemus sylvaticus } & & \multicolumn{3}{c}{ Pitymys duodecimcostatus } \\
\cline { 2 - 3 } & Body weight & CBL & $\begin{array}{c}\text { Cristaline } \\
\text { weight }\end{array}$ & & Body weight & CBL & $\begin{array}{c}\text { Cristaline } \\
\text { weight }\end{array}$ \\
\hline Body weight & 1.00 & & & & 1.00 & & \\
CBL & $0.94^{* * *}$ & 1.00 & & & 0.19 & 1.00 & \\
Cristaline wt & $0.91^{* * *}$ & $0.97^{* * *}$ & 1.00 & & $0.60^{*}$ & 0.03 & 1.00 \\
RBC & -0.21 & -0.19 & -0.22 & & 0.22 & -0.08 & 0.22 \\
Hb & -0.13 & -0.06 & -0.14 & & 0.30 & -0.06 & 0.18 \\
Hc & -0.19 & -0.04 & -0.21 & & 0.21 & -0.08 & 0.12 \\
\hline
\end{tabular}

Table 3. Seasonal changes of hematological values and relative heart weight (mean $\pm \mathrm{SE}$ ) of Apodemus sylvaticus and Pitymys duodecimcostatus. Statistical significance ANOVA (ns $=$ not significant, $\left.{ }^{*} p<0.05,{ }^{* *} p<0.01,{ }^{* * *} p<0.001\right)$.

\begin{tabular}{|c|c|c|c|c|c|}
\hline Variable & Sign. & Autumn & Winter & Spring & Summer \\
\hline \multicolumn{6}{|l|}{ A. sylvaticus } \\
\hline $\operatorname{RBC}\left(10^{6} / \mathrm{mm}^{3}\right)$ & ns & $9.86 \pm 0.23$ & $9.52 \pm 0.31$ & $9.39 \pm 0.26$ & $9.21 \pm 0.32$ \\
\hline $\mathrm{Hb} \quad(\mathrm{g} / \mathrm{dl})$ & $*$ & $14.90 \pm 0.23$ & $14.61 \pm 0.37$ & $15.03 \pm 0.27$ & $13.74 \pm 0.48$ \\
\hline$(\%)$ & $* *$ & $49.47 \pm 0.54$ & $46.13 \pm 0.79$ & $46.85 \pm 0.94$ & $43.13 \pm 1.03$ \\
\hline $\operatorname{MCV}\left(\mu^{3}\right)$ & ns & $49.83 \pm 0.96$ & $48.51 \pm 1.18$ & $50.23 \pm 1.16$ & $46.95 \pm 1.03$ \\
\hline $\mathrm{MCH} \quad$ (pg) & ns & $15.07 \pm 0.34$ & $15.25 \pm 0.36$ & $15.98 \pm 0.48$ & $14.97 \pm 0.34$ \\
\hline $\mathrm{MCHC}(\mathrm{g} \%)$ & ns & $30.75 \pm 0.37$ & $32.24 \pm 0.82$ & $32.07 \pm 0.44$ & $32.30 \pm 0.52$ \\
\hline $\begin{array}{l}\text { Realtive heart } \\
\text { weight }(\mathrm{mg} / \mathrm{g})\end{array}$ & * & $7.92 \pm$ & $8.30 \pm$ & $7.52 \pm$ & $7.36 \pm 0.09$ \\
\hline $\mathrm{n}$ & & 22 & 22 & 28 & 23 \\
\hline \multicolumn{6}{|l|}{ P. duodecimcostatus } \\
\hline RBC $\quad\left(10^{6} / \mathrm{mm}^{3}\right)$ & ns & $10.85 \pm 0.49$ & $13.09 \pm 0.45$ & $11.66 \pm 0.26$ & $10.93 \pm 0.27$ \\
\hline$(\mathrm{g} / \mathrm{dl})$ & $* * *$ & $14.52 \pm 0$ & $15.83 \pm 0$ & $15.93 \pm 0$ & $13.25 \pm 0.44$ \\
\hline$(\%)$ & $* * *$ & $46.62 \pm 1.52$ & $51.81 \pm 0.84$ & $47.61 \pm 0.87$ & $43.94 \pm 0.85$ \\
\hline $\operatorname{MCV} \quad\left(\mu^{3}\right)$ & ns & $45.07 \pm$ & $43.69 \pm 1.07$ & $41.85 \pm 0.87$ & $40.72 \pm 0.99$ \\
\hline $\mathrm{MCH} \quad(\mathrm{pg})$ & ns & $13.27 \pm 0.30$ & $13.54 \pm 0.31$ & $13.96 \pm 0.36$ & $12.23 \pm 0.47$ \\
\hline $\mathrm{MCHC}(\mathrm{g} \%)$ & $* *$ & $31.26 \pm 0.51$ & $30.07 \pm 0.77$ & $33.15 \pm 0.51$ & $30.30 \pm 0.73$ \\
\hline $\begin{array}{l}\text { Realtive heart } \\
\text { weight }(\mathrm{mg} / \mathrm{g}) \\
\mathrm{n}\end{array}$ & $* * *$ & $\frac{6.78 \pm 0.14}{12}$ & $\begin{array}{c}7.96 \pm 0.25 \\
23\end{array}$ & $\begin{array}{c}7.20 \pm 0.29 \\
35\end{array}$ & $\begin{array}{c}7.53 \pm 0.09 \\
10\end{array}$ \\
\hline
\end{tabular}

Seasonal variations

The seasonal variations in hematological values were studied by two way ANOVA and they were significantly affected by sex or gestation. Table 3 shows both the seasonal hematological values and relative heart weights for $A$. sylvaticus and $P$. duodecimcostatus during the year, as well as their statistical significance. Although $\mathrm{RBC}$ were not significant in A. sylvaticus, the hoghest value was found in autumn and the lowest in summer. RBC varied significantly in $P$. duodecimcostatus $(p<0.05)$. The summer values were highest and differed significantly from those of the other three seasons. 
Seasonal differences in $\mathrm{Hb}$ concentration were significant in both A. sylvaticus $(p<0.05)$ and $P$. duodecimcostatus $(p<0.001)$. The autumn, winter and spring values for the mouse were similar while those for summer were comparatively lower. This difference between summer and the other three seasons was statistically significant. $\mathrm{The} \mathrm{Hb}$ values in the vole were high in winter and spring, and lower in summer. The seasonal differences between winter-spring and summer-autumn were significant.

The seasonal differences in hematocrit $(\mathrm{Hc})$ values were significant in both species. The highest $\mathrm{Hc}$ value in $A$. sylvaticus was found in autumn after which $\mathrm{Hc}$ decreased during winter and spring to its lower value in summer. A significant difference was found between autumn and the other seasons. In $P$. duodececimcostatus the highest value was found in winter and the lowest in summer. Differences between winter and the other seasons were significant.

No significant seasonal differences in MCV values were found in either species. The highest values for this index in A. sylvaticus were found in autumn and spring. The values in $P$. duodecimcostatus decreased progressively from autumn through winter and spring to summer.

In $A$. sylvaticus $\mathrm{MCH}$ did not vary significantly, although there was a slight increase from autumn to spring which levelled off during the summer. In $P$. duodecimcostatus $\mathrm{MCH}$ variations were significant $(p<0.01)$. The value was similar in autumn, winter and spring but lower in summer. The significant differences was between summer, and the other seasons.

A. sylvaticus $\mathrm{MCHC}$ values did not vary significantly over the seasons. However, the differences in $P$. duodecimcostatus were significant $(p<0.001)$ with a high MCHC in spring. The difference between spring and the other seasons was significant.

In both $A$. sylvaticus and $P$. duodecimcostatus the seasonal variation in relative heart weight was significant ( $p<0.05$ and $p<0.001$, respectively), being higher in winter than in summer.

The differences between the winter and spring, and the spring and summer seasons in A. sylvaticus were significant. For the $P$. duodecimcostatus the significant difference was between winter and the other three seasons.

\section{Discussion}

The quantity of blood hemoglobin is affected by the characteristic energy requirements and metabolic rate of each species. The relations between $\mathrm{Hb}$ concentration and body size (Kunicki-Goldfinger and Kunicka-Goldfinger 1964, Sealander 1964, Lee and Brown 1970, Wołk 1974), and Hb and altitude (Kalabuchov 1953, Sealander 1964), is inverse, not allometric. These variables cannot be taken into acount in our study, since specimens had similar geographic origin and weights.

The polycytemia presented by $P$. duodecimcostatus, in comparison to A. sylvaticus, has low MCV values and can be explained as a mechanism to allow the increase of the total gas exchange. This has been described by different authors (Kostelec- 
ka-Myrcha 1966b, Withers 1975, Ar et al. 1977, Boggs et al. 1984) in various burrowing animals.

Hematologic studies carried out by Palacios (1976) confirm that the number of erythrocytes and $\mathrm{Hb}$ concentration are higher in small members of the Microtinae family than in the Murinae family. According to Palacios, this may be caused by the higher metabolic rate in the Microtinae. The MCHC values for both species were similar to those cited by Hawkey (1975) for other mammals.

\section{The effect of sex and gestation on hematological parameters}

The lack of sexual dimorphism in the hematological variables of both $P$. duodecimcostatus and A. sylvaticus is also true of other small mammals (Sealander 1960, 1962, 1964, Kunicki-Goldfinger and Kunicka-Goldfinger 1964, Kostelecka-Myrcha 1967, Wołk 1974, Scelza and Knoll 1982). During pregnancy, A. sylvaticus has lower $\mathrm{Hb}, \mathrm{Hc}$ and $\mathrm{RBC}$ values, while only $\mathrm{RBC}$ and $\mathrm{Hc}$ decrease in nonpregnant females in P. duodecimcostatus. Similar data have been found by Sealander (1964), and Kostelecka-Myrcha (1967) in other small mammals.

\section{Effect of age on hematological parameters}

The absence of significant variation with age in the hematological values found in A. sylvaticus and $P$. duodecimcostatus agrees with other authors (Kunicki-Goldfinger and Kunicka-Goldfinger 1964, Sealander 1964, Kostelecka-Myrcha 1967, Palacios 1976). Kostelecka-Myrcha (1966a, 1967) observed that the hematological values in Pitymys subterraneus and Clethrionomys glareolus stabilized one month after birth.

Seasonal variations in hematological parameters and relative heart weight

The seasonal variations in hematological values found in P. duodecimcostatus and A. sylvaticus follow different patterns, although the lower $\mathrm{Hb}$ concentration, $\mathrm{Hc}$, $\mathrm{MCV}$, and $\mathrm{MCH}$ values all found during summer.

The seasonal characteristics found in other small mammals for these variables consist of increased $\mathrm{Hb}$ and $\mathrm{Hc}$ concentrations and $\mathrm{RBC}$ values with low $\mathrm{MCV}$ values in winter which then reverse during summer. Many authors have related this seasonal variation to environmental acclimatization (Newson 1962, Newson and Chitty 1962, Sealander 1962, 1964, Kostelecka-Myrcha 1967, Lee and Brown 1970, Wołk 1974, Rewkiewicz-Dziarska 1975, Palacios 1976). They suggest that winter cold produces a period of intense thermogenesis that leads to increased respiratory function and, among other adaptations, supposes an increase in $\mathrm{Hb}$ concentration and the number of $\mathrm{RBC}$. As a result, capacity for oxygen transport would increase and the total available area for gas exchange would be enlarged.

This scheme for the seasonal variation to hematological parameters is followed by $P$. duodecimcostatus in part with high $\mathrm{RBC}, \mathrm{Hb}$ and $\mathrm{Hc}$ values in the winter-spring period that decrease during summer and autumn. Lee and Brown (1970), in their studies on burrowing rodents, observed that the general lack of available oxygen in the 
burrows could worsen during winter and so contribute to the increase in the $\mathrm{Hb}$ concentration.

$P$. duodecimcostatus also showed a significant seasonal variation in MCHC. This hematologic index reflects erythropoiesis and may be affected by diet, particularly $\mathrm{Fe}$ deficiencies (Kunicki-Goldfinger and Kunicka-Goldfinger 1964, Bernard and Levy 1983) or by lack of oxygen. In our case, we can only mention these findings since the causes for this variation are not under study here. A. sylvaticus did not show the same hematological variation pattern mentioned above, and with the exception of higher autumn $\mathrm{Hc}$, the other hematological variables oscillated only slightly through the different seasons of the year. This lack of seasonal variation is not surprising since there are reports of other rodents that do not follow the winter-summer hematic cycle. Kalabukhov (1953) found a greater $\mathrm{Hb}$ concentration in winter than in summer in A. flavicollis. Sealander (1966) found no hematological changes in the different seasons in C. rutilus. He explained this as being a result of the uniform habitat temperature. Recently, Puchalski and Heldmaier (1986) studied seasonal hematological variations in hamster. They created two experimental groups, one exposed to seasonal and temperature variations and the other had thermoneutral conditions. The differences in $\mathrm{Hb}$ concentration between the two groups were not significant, although $\mathrm{RBC}$ did varied, suggesting that these parameters are fundamentally influenced by the photoperiod.

In addition to the mechanisms that have been mentioned, there are others that increase blood capacity for oxygen transportation, such as increased respiratory rate or cardiac output. Kostelecka-Myrcha (1967) found greater relative heart weights in those $C$. glareolus that lived at high altitudes, and interpreted this as an adaptation mechanism to increase the oxygen demands at low $\mathrm{O}_{2}$ pressure since no differences were observed in the hematological values.

Sealander (1966), in C. rutilus, and Heroux (1961), and Puchalski and Heldmaier (1986), in hamster, noted an increase in relative heart weight during the cold months, which might be indicative of a seasonal change. The physiological impact of an increase in heart weight is obvious, since improved circulatory efficiency is obtained by an increase in cardiac output per unit of body weight. In our study, we have found seasonal variation in the relative heart weight in the two species, $A$. sylvaticus and $P$. duodecimcostatus, since the greatest relative heart weight was found during winter, and, therefore, could contribute as another factor of seasonal acclimatization.

\section{References}

Ar A., Arieli R. and Shkolnik A. 1977. Blood-gas properties and function in the fossorial mole rat under normal and hypoxic-hypercapnic atmospheric conditions. Res. Physiol. 30: 201-218.

Bartnett J. L., How R. A. and Humphreys W. F. 1979. Blood parameters in natural populations of Trichosurus species (Marsupialia: Phalangeridae). II. Influence of habitat and population strategies of T. caninus and T. vulpecula. Aust. J. Zool. 27: 927-938.

Bernard J. and Levy J. P. 1983. Manual de hematologia. Ed. Toray-Masson: 47-64. 
Boggs D. F., Kilgore D. L. and Richard G. F. 1984. Respiratory physiology of burrowing mammals and birds. Comp. Biochem. Physiol. 77A: 1-7.

Dudziński M. L., Hesterman E. R. Y. and Mykytowicz R. 1962. Some haematological data from an experimental colony of rabbits, Oryctolagus cuniculus. Austral. J. Zool. 10: 587-596.

Hawkey C. M. 1975. Comparative haematology of the vertebrates. [In: Comparative mammalian haematology. eds]. Whitegriars Press Ltd., London: 3-15.

Heroux D. 1961. Climatic and temperature induced changes in mammals. Rev. Can. Biol. 20: 55-68.

Kalabukhov N. J. 1953. Some physiological adaptations of the mountain and plain forms of the woodmouse (Apodemus sylvaticus) and of other species of mouse like rodents. J. Anim. Ecol. 6: 254-272.

Kostelecka-Myrcha A. 1966a. Erythrocytes, hemoglobin and hematocrit in the postnatal development of Pitymys subterraneus (de Sélys-Longchamps, 1836) (Mammalia, Microtidae). Bull. Acad. Pol. Sci., Cl. II 14: 413-418.

Kostelecka-Myrcha A. 1966b. Hemoglobin, erythrocytes and hematocrit in the blood of some Microtidae under laboratory conditions. Bull. Acad. Pol. Sci., Cl. II 14: 343-345.

Kostelecka-Myrcha A. 1967. Variation of morpho-physiological indices of blood in Clethrionomys glareolus (Schreber, 1780). Acta theriol. 12: 191-222.

Kunicki-Goldfinger W. and Kunicka-Goldfinger W. 1964. Seasonal variations of some haematological values in small mammals living in natural environment. Acta theriol. 9: 149-164.

Lee K. A. and Brown J. H. 1970. Variations in the hemoglobin concentrations of Great Basin rodents. J. Mammal. 51: 669-674.

Malzahn E. 1974. Tissue metabolism in the Common shrew and the Bank vole. Acta theriol. 19: 301-314.

Newson J. 1962. Seasonal differences in reticulocyte count, hemoglobin level and spleen weight in wild voles. Brit. J. Haemat. 8: 296-302.

Newson J. and Chitty D. 1962. Haemoglobin level, growth and survival in two microtus populations. Ecology 43: $733-738$.

Palacios L. 1976. Contribución al estudio del transporte del oxígeno en los mamíferos durante su exposición al frio. Ph. D. thesis, University of Barcelona.

Puchalski W. and Heldmaier G. 1986. Seasonal changes of heart weight and erytrocytes in the Djungarian hamster Phodopus sungorus. Comp. Biochem. Physiol. 82A: 259-263.

Rewkiewicz-Dziarska A. 1975. Seasonal changes in hemoglobin and erytrocyte indices in Microtus arvalis (Pallas, 1779). Bull. Acad. Pol. Sci., Cl. II 23: 481-488.

Scelza J. and Knoll J. 1982. Seasonal variation in various blood indices of the Kanguroo rat Dipodomys panamintinus. Comp. Biochem. Physiol. 71 (A): 237-240.

Sealander J. A. 1960. Hematological changes in deer mice acclimated at different ambient temperatures. Amer. J. Physiol. 198: 195-199.

Sealander J. A. 1962. Seasonal changes in blood values of deer mice and other small mammals. Ecology 43 : 107-119.

Sealander J. A. 1964. The influence of body size, season, sex, age, and other factor upon some blood parameters in small mammals. J. Mammal. 45: 598-616.

Sealander J. A. 1966. Seasonal variation in hemoglobin and hematocrit values in the northern red backed mouse Clethrionomys rutilis dawsoni (Merriam) in interior Alaska. Can. J. Zool. 44: 213-224.

Withers P. C. 1975. A comparison of respiratory adaptation of semifossorial and a surface dweling Australian rodent. J. Comp. Physiol. 98: 193-203.

Wołk E. 1974. Variations in the hematological parameters of shrews. Acta theriol. 19: 315-346.

Received 19 June 1989, accepted 20 July 1990. 